\title{
NEFH Gene
}

National Cancer Institute

\section{Source}

National Cancer Institute. NEFH Gene. NCI Thesaurus. Code C88038.

This gene is plays a role in neuronal structure. 